\title{
Maritime Security and Geopolitics in the Indo-Pacific Region
}

\author{
Gurpreet Singh Khurana*
}

Abstract

The centre-of-gravity of world's economic power is shifting eastwards to the 'Indo-Pacific', a maritimeconfigured macro-region that spans the maritime underbelly of Asia connecting the Indian and the western Pacific oceans. The security environment in the Indian Ocean and the western Pacific are different; nonetheless, strong maritime security linkages emerging between the two oceans has led to the reincarnation of the concept of 'Indo-Pacific'. Since the turn of the 21st century, new maritime insecurities have taken root, including in terms of China's revisionist positions on the established maritime order. Notwithstanding the US response in the western Pacific and the recent articulation of its 'IndoPacific' strategy, it is unclear how the regional countries and the major regional stakeholders willmanage to address the emerging maritime insecurities in the Indian Ocean, including in terms of China's expanding politicomilitary footprint. This paper attempts to examine the security environment and geopolitics in the Indo-Pacific in context of India's national security interests.

Keywords: Indo-Pacific Geopolitics, PLA Navy, Chinese Strategy

\section{Introduction}

The Indian Ocean Region (IOR) and Western Pacific rim represent the maritime space of the Afro-Asian macro-region that is being

\footnotetext{
* National Maritime Foundation (NMF), New Delhi, India; gurpreet.bulbul@gmail.com
} 
increasingly referred to as the 'Indo-Pacific' region. Since 2010, the concept of 'Indo-Pacific' has gained prevalence in the geopolitical and strategic discourse, and is now being used increasingly by policy-makers, analysts and academics in Asia and beyond. It is now precisely a decade since the concept was proposed by Khurana in 2007. Although the Australians have been using the term 'Indo-Pacific' earlier, it was for the first time, at least in recent decades, that the concept was formally introduced and explained in an academic paper (Khurana, 2007, 2019).

\subsection{Regional Security Environment}

In comparison to the rest of the world, the maritime-configured Indo-Pacific region is plagued more by insecurities. The nature and character of such insecurities across the Indo-Pacific region is not uniform. Even though there are some issues that involve the entire region, the predominant issues in the East China Sea and South China Sea, for example, are very different than those in the Western Indian Ocean, and in a sense, present contrasts and contradictions.Nonetheless, four aspects are distinct and germane to the understanding of the broader security environment in the Indo-Pacific region.

The first pertains to the very concept of "maritime security". Unlike in the developed West where the concept refers only to nontraditional security threats, including those posed by non-state actors, for the countries of the Indo-Pacific region, traditional military challenges and issues of territorial sovereignty form a major part of the concept of 'maritime security'. Also, as characteristic of the maritime realm in general, there is a very hazy dividing line between non-traditional and traditional security issues, with overlaps between the two, or non-traditional threats reinforcing traditional military insecurities. Take, for instance, China's financial investment in Sri Lanka's Hambantota port project, which has lately turned into a 'debt trap' for Colombo. While the financial leverage that Beijing wields against Colombo is a non-traditional security issue for Sri Lanka, the handling of the port's internal security by Chinese personnel and the enhanced 
likelihood of PLA Navy's submarine activity off Hambantota have increased the level of traditional military threat to India.

Secondly, in the IOR, many of the countries are economically underdeveloped with inadequate state capacity to regulate human activity even on their land territories; much less to ensure good order and human security in their extensive maritime zones and beyond. On the other hand, the Western Pacific rim countries are beset by insecurities that are more a result of traditional military threats due to territorial issues, and military imbalances, much of it a residue of history. In total, the Indo-Pacific countries are in nascent stages of evolution as nation-states vis-à-vis the West, either in terms of their economic power and state capacity or in terms of their territorial consolidation.

Thirdly, even while some issues seem to be specific to either the Indian Ocean or Western Pacific Ocean, the linkage between the two areas has always existed. The sea-borne nuclear and missile proliferation network involving China, Pakistan and North Korea is case in point. Such links between the two areas are becoming increasingly strong and evident. This is one of the major reasons why the term 'Indo-Pacific' has lately been added to the geopolitical lexicon of analysts.

Fourthly, many extra-regional powers are major stakeholders in the region and therefore have continued to play a dominant security role in the Indo-Pacific region albeit to secure their own interests that may or may not be convergent with those of the regional countries." Although the role of such extra-regional stakeholders is necessary for regional security and stability, paradoxically, it leads to concomitant insecurities and instability due to heightened rivalries, making the regional security environment geopolitics highly complex.

\subsection{Salient Maritime Security issues}

The maritime security issues like maritime terrorism and crimes, issues linked with maritime jurisdiction and sustainable exploitation of resources, issues concerning human safety, and so on, are well known, and so are their causes and much has been 
written about these issues in detail. This paper, therefore, makes an attempt to examine select issues that have direct consequences on India and its regional neighbourhood. It also tries to extrapolate the maritime security challenges and trends into the medium-to-long term time frame. Although such extrapolation is based on an estimate and is very tentative, it could contribute much to enrich the current discourse and prepare the regional countries and other stakeholders for the future. For analytical convenience, this paper divides the Indo-Pacific region, into three distinct areas - the western Indian Ocean, the eastern Indian Ocean, and the western Pacific Ocean.

\subsection{Maritime Piracy}

Piracy in the western Indian Ocean made the period between 2005 and 2012 rather tumultuous for all regional countries and stakeholders. The comprehensive counter-piracy response ranging from UNSC's authorisations to multi-national naval missions and shipping community's Best Management Practices (BMP) -effectively dealt with the menace.

However, legal issues have continued to pose a major challenge. Earlier, India was confronted with the legal voids to prosecute the pirates. This issue was never resolved, and India tided over it through transient politico-diplomatic arrangements. In addition, India is now saddled with additional legal complexities pertaining to the Private Maritime Security Companies (PMSC), Vessel Protection Detachments (VPDs) and 'floating armouries'. So now it is an unenviable position of legal ambiguities, which are more complex than the situation we faced in 2005. Can the private sector take over the roles of states for providing security? Who would authorize rules of engagement for the private guards? Such practice establishes dangerous precedents in terms of the risk of inadvertent or accidental use of force. The case of MV Enrica Lexie (2012) is illustrative of the enhanced risks. Besides, the emergence of 'floating armories' within the maritime zones of coastal states not only conflicts with their domestic laws, but also endangers their security (Chatterjee, 2014). The case of MV Seaman Guard Ohio (2013) is a case in point. The particular vessel may have been 
operating for benign ends, but such practice may be used as a cover for arms trafficking, or even as depot ships for terrorists and other militants (Greenberg, 2006).

In 2015, the International Maritime Organisation (IMO), in conjunction with the shipping industry and the flag states promulgated ISO 28007-1:2015 guidelines to standardise the practice and regulate PMSCs. The regulations address the command relationship between the master and the Privately Contracted Armed Security Personnel (PCASP), Rules of Engagement (RoE) and questions of liability. However, many other legal issues such as the use of force against persons on board foreign-flagged ships and carriage of weapons in foreign territorial waters and ports ('floating armouries') remain unaddressed. The 'bottom-line' remains that the practice of employing PMSCs on board merchant ships is not-and cannot be-circumscribed by any international law, given the existing Westphalian international order wherein only States - and State agencies - are given the legal right to use violent means.

The pirate attacks off Somalia have subsided since 2013 due to effective countermeasures. But until instability and deprivation persist in the area, and the constraints of local maritime forces are addressed, there is a potential for piracy to resurface when the prevailing 'deterrent-effect' wears off and the multinational naval forces withdraw from the area.

\subsection{Maritime Terrorism}

Until a half-decade ago, the Sea Tigers of the Liberation Tigers of Tamil Eelam (LTTE) was a Sri Lankan militant group well known for its resort to maritime terrorism. While it was wiped out in 2010, there is a high potential for this maritime threat to reappear in the western Indian Ocean in the form of religious radical ideology spilling-over into the sea. The militant group called the Islamic State of Iraq and Syria (ISIS) seeks to create an Islamic state or caliphate. In August 2015, it claimed to have begun the usage of its own currency (The Statesman, 2015). For its economic sustenance, maritime access and communications would be essential for the 
ISIS-governed state. For instance, the ISIS possesses expansive oilfields in northern Iraq, but this is of little use until it can export the oil. The ISIS may have plans to build a navy, but any nascent navy would need to resort to asymmetric means, similar to the Sea Tigers. In July 2015, a Sinai-based group affiliated to ISIS destroyed an Egyptian coast-guard ship using a missile (BBC News, 2015). This incident reinforces the budding capability of ISIS for 'maritime jihad'. Such an asymmetric naval force could pose a major threat to freedom of navigation. If the ISIS expands the territory under its control to have access to the Persian Gulf, the Strait of Hormuz would become highly insecure and vulnerable to being choked. If ISIS were to succeed, the movement could spill-over to Southeast Asia to revive the Jammah Islamiyah (JI) movement.

The religious fundamentalist group $\mathrm{Al}$ Qaeda could also resort to 'maritime jihad'. Although it disowned ISIS in February 2014 on the basis of political objectives, (The Washington Times, 2014) its radical ideology is similar to that of ISIS. The hijacking of Pakistani warship PNS Zulfiqar by Al Qaeda operatives in September 2014 represents the empirical evidence of the same. Three days before the Zulfiqar incident, Al Qaeda had declared its intent to carry its 'jihad' to the Indian sub-continent. Evidently, the osmosis of such ideology to South Asia has already begun. News reportage emanating from the Maldives is highlighting the rise of radical Islam in the island country (Hamid, 2015). In September 2015, Bangladeshi intelligence authorities unearthed a plan of some Islamist groups to target naval bases and refineries in Chittagong (Times of India, 2015). Hence, radical ideology is seen to be moving eastwards towards India. This is leading to an added potential threat to Indian naval assets and infrastructure, besides the existing threat to the 'softer' targets in India like offshore installations and ports. Given the ample evidence that the terrorists who attacked Mumbai in November 2008 were trained by the Pakistan Navy, the Indian security establishment cannot take these developments lightly.

From the Indian perspective, this represents major insecurity. From the broader perspective too, the expansion of religious 
fundamentalism eastwards is potentially dangerous since it could potentially engulf the entire IOR and even Southeast Asia, linking up with the JI movement that is currently dormant.

While the capacity void of the regional countries poses a challenge to combat piracy, it is more relevant in the context of maritime terrorism. Most regional maritime forces could be overwhelmed by a motivated and well-equipped terrorist group, particularly when it resorts to asymmetric means. It may be recalled that in early2014, ISIS forces used anti-tank guided weapons to destroy five M1A1 Abrams tanks of the Iraqi army and shot down six of its helicopters using light anti-aircraft guns and rocket launchers (Pianin, 2014). Very few countries in the western IOR possess adequate naval capability, even for force-protection, let alone undertaking dedicated counter-terrorism operations at sea. Purportedly, among the most relevant ones with the potential to contribute are Pakistan, India, and Iran.

Pakistan - The Pakistan Navy is contributing to the US-led Combined Maritime Forces (CMF) Task Force-151's counter-piracy effort. However, its credibility to effectively contribute to counter maritime terrorism is doubtful, given the growing radicalisation of its military and its India-specific military strategy.

India - While New Delhi seeks to give effect to its normative role as a regional security provider, it may be compelled to focus its maritime-military capability to counter the emerging threats of proxy-war emanating from Pakistan - through (punitive) active deterrence, if required - rather than employ its forces in the regional context.

Iran - In the past, Iran itself has issued threats to block the International Shipping Lane (ISL) transiting the Strait of Hormuz. Tehran's role in the conflict in Yemen, and its emerging confrontation with the US and the other Persian Gulf countries lends much ambiguity to its potential role to counter maritime terrorism. 
This has led to the need to involve coalition forces led by extraregional stakeholders to ensure maritime security in the IOR, which has its own pitfalls (addressed later).

\subsection{The Capability Contrast}

The Indo-Pacific region is marked by contrasting naval capabilities. The eastern IOR and the Western Pacific are marked by a proliferation of sea-denial capabilities, particularly submarines. The table below indicatesthat in 15 years after 2010, the region would be adding close to a hundred submarines amounting to about oneand-half times the current force levels (The data excludes obsolete and midget submarines that cannot be deployed beyond coastal waters).

\begin{tabular}{|c|c|c|}
\hline Country & 2010 & $\begin{array}{c}\text { Beyond } 2025 \text { (Projected } \\
\text { Estimates) } \\
\end{array}$ \\
\hline $\begin{array}{l}\text { South } \\
\text { Africa }\end{array}$ & $3(209-1400)$ & 3 \\
\hline Iran & 3 (Kilo) & 3 \\
\hline Pakistan & 5 (Agousta 70/90B) & $\begin{array}{l}11 \text { (Agousta 90B/Chinese } \\
\text { Yuan/AIP) }\end{array}$ \\
\hline India & $\begin{array}{l}16(\text { Kilo/209/ } \\
\text { Foxtrot) }\end{array}$ & $\begin{array}{l}18 \text { (Kilo/209/ P-15 Scorpene) }+2 \\
\text { SSN+ } 2 \text { SSBN }\end{array}$ \\
\hline Bangladesh & - & 2 (Chinese Ming) \\
\hline Thailand & - & 3 (Chinese Yuan) \\
\hline Myanmar & - & 1 (Indian Kilo) \\
\hline Indonesia & 2 (Type 209) & 5 (3 ROK-built 209/1200+ 2 Kilo) \\
\hline Malaysia & $\begin{array}{l}2 \text { (Scorpene-class } \\
\text { inducted in 2009) }\end{array}$ & 2 \\
\hline Singapore & $\begin{array}{l}4 \text { (Challenger/ } \\
\text { Sjoorman) }\end{array}$ & 4 (2 Vastergotland + 2 Type 218 ) \\
\hline Vietnam & - & 6 (Kilo) \\
\hline China & $\begin{array}{l}\text { 30(Song/Yuan/Kilo) } \\
+2 \text { SSN (093) + } 3 \\
\text { SSBN (094) }\end{array}$ & $\begin{array}{l}54 \text { (Song/Yuan/Kilo) + } 7 \text { SSN } \\
(093 / 095)+6 \text { SSBN }(094 / 096)\end{array}$ \\
\hline Taiwan & $\begin{array}{l}04 \text { (Hai Lung/ } \\
\text { Guppy II) }\end{array}$ & 12 \\
\hline Japan & $\begin{array}{l}19 \text { (Souryu/ } \\
\text { Oyashio/Harushio) }\end{array}$ & 23 (additional 04 Soryu) \\
\hline ROK & $12(209-1200 / 214-$ & 18 (214-KSS2/ KSS3) \\
\hline
\end{tabular}


KSS-2)

\begin{tabular}{|c|c|c|}
\hline Russia & $\begin{array}{l}20 \text { (Lada/ Kilo) + } 25 \\
\text { SSN (Sierra/Oscar } \\
\text { II/ Akula/ Victor } \\
\text { III....) + } 15 \text { SSBN } \\
\text { (Typhoon/ Delta/ } \\
\text { Borey) }\end{array}$ & $\begin{array}{l}22 \text { (additional } 2 \text { Lada) }+27 \text { SSN } \\
\text { (additional } 2 \text { Yasen) }+19 \text { SSBN } \\
\text { (additional } 4 \text { Borey) }\end{array}$ \\
\hline Total & 171 & 263 \\
\hline
\end{tabular}

Fig 1. The proliferation of Submarines in the Indo-Pacific (West to East) (Jane's Fighting Ships 2010-2011 et al.)

It must be noted that this trend also stands in stark contrast to the rest of the world, wherewith the possible exceptions of a couple of countries in Latin America like Brazil and Venezuela - the submarine force-levels are not increasing.

Understandably, such capability is meant for deterrence and cater for worst-case scenarios, and thus for reassurance and increasing the level of security. However, paradoxically, it is likely to lead to enhanced non-traditional insecurity at the regional level over various issues like water space management, de-confliction of unintentional encounters and response to submarine emergencies and rescue. Due to the sensitive nature of submarine operations, the regional countries are unlikely to be forthcoming to share information on their submarine movements and deployment areas, which adds to the complexity of the issue.

\section{Marine Resource Management}

While the countries in the eastern IOR and Western Pacific rim build high-end sea-denial capabilities, many of these - particularly in the western IOR lack the basic maritime capacity to enforce order in their extensive maritime zones, leading to unsustainable exploitation of resources, particularly overfishing, and degradation of their marine environment.

\subsection{Maritime Disputes}

Until less than a decade ago, the predominant maritime insecurity in the WP had the potential of a conflict over Taiwan and its 
adverse implications on freedom of navigation (FON). Although the maritime disputes in the South China Sea (SCS) andEast China Sea (ECS) were there, these were not in the focus. Today these disputes have not only taken centre-stage, but have become more complex, involving more countries and the extra-regional powers, notably the US. The scope of disputes has also increased in terms of the issues involved, which may have adverse ramifications for the regional countries and other stakeholders. These issues include:

- Enlarged geographic/geopolitical scope

- Freedom of navigation/over-flight versus Foreign Military Activity in Exclusive Economic Zones (EEZ)

- US-China military brinkmanship, including operational concepts such as China's Anti-Access/Area-Denial (A2/AD) versus the US Air-Sea Battle (ASB), which has now been rechristened as Joint Access and Manoeuvre in the Global Commons (GCJAM).

- Access to resources based on tenets of international law

- Upholding other norms of international law on:

- Resolution of maritime claims

- Dispute settlement

Lately, the maritime disputes eastwards of India have usually been more 'visible', either due to their intractable nature (in the Western Pacific rim) or due to the tangible progress made through international arbitrations (in the Bay of Bengal/IndonesiaPhilippines dispute settlement). The ones in India's west have been dormant; and hence, rarely come into the limelight. There are many such disputes that dot the western Indian Ocean stretching from the Red Sea and Persian Gulf to the areas around Madagascar and the Chaos Archipelago. Among these conflicts, there is one between India and Pakistan over Sir Creek and related maritime boundary delineation.

The claimant countries are not asserting their claims militarily (in contrast to the littorals of the Western Pacific rim). Interestingly; the 
dormancy of these disputes may be due to an exceptional positive spin-off of the lack of their maritime-military capacities.

How and when will these be resolved? It is indeed difficult to arrive at a consensus regarding the number. The demonstrated will of countries in the Bay of Bengal - and some other Southeast Asian countries - to refer their maritime contentions to international tribunals may set positive precedents for the other countries. However, it is also possible that as they develop naval capabilities, the countries of the western Indian Ocean may tend to emulate the military assertion of the littorals in the western Pacific. This possibility bears the potential for a major instability in the area in the coming decades.

\subsection{Irregular Sea-borne Migration}

The eastern Indian Ocean is severely affected by the migrations of the Rohingyas from Bangladesh and Myanmar, and the Sri Lankan Tamils to the well-off countries of Southeast Asia and Australia. These migrations are not yet as serious as the migrations further west of the Indian Ocean, where asylum seekers from West Asia and northern Africa are crossing the Mediterranean Sea to throng the various camps in Europe. But if ISIS were to expand to Southeast Asia, this could become a big issue.

Over the medium-to-long term timeframe, nature could be another cause for mass migrations. Climate-induced sea-level rise and natural disasters could lead to unprecedented mass emigration from low-lying countries in the area, particularly the island states. This could lead to major humanitarian crises, with strong regional and global ramifications.

One aspect concerning mass migration is the voids or constraints of international law. The migrations in the eastern Indian Ocean are largely economic, and thus not covered by the legal provisions on the obligation of states to grant asylum. The dated 'Convention Relating to the Status of Refugees' of 1951 (Refugee Convention, 1951) and its 1967 Protocol (UNHCR, 2010) cater only for political asylum-seekers, and not to those who are compelled to migrate due to economic deprivation and lack of opportunities to earn a 
livelihood. It may also be necessary for international law to cater for contingencies involving a large-scale displacement of people forced by nature.

\subsection{Maritime Search and Rescue}

An attendant issue of maritime is Search and Rescue (SAR). In the predominantly maritime-configured Indo-Pacific region with increasing traffic - both by sea and air - the aspect of SAR is a stand-alone problem as well. The series of recent accidents like the disappearance of Malaysian airline MH-370 in March 2014 and the sinking of the South Korean ferry in April 2014 led to the realization of the lack of effectiveness and efficiency of SAR coordination among the regional countries, as well as between the aeronautical and maritime elements of the national SAR structures. Notably, many countries are not parties to the SAR Convention 1979. Another major void is the lack of SAR capacity of the regional countries, particularly in relation to the geographical extent of SAR regions allotted to them.

Many regional countries have not even ratified the SAR Convention. Amongst the major reason is their sensitivities over the issue of sovereignty. This is closely linked to their apprehensions about the potential actions of the major extraregional powers. This leads to the issue of geopolitics in the region.

\subsection{The Geopolitical Dimension}

As indicated earlier, many extra-regional powers are major stakeholders in the region and therefore have continued to play a dominant security role in the Indo-Pacific region. Their role is essentially premised either on meeting their alliance commitments or delivering public goods as part of their normative international obligations. The multilateral security forums in the region are amenable to such an 'inclusive' approach to regional security for two good reasons: the need for regional countries to resort to hedging/strategic deterrence, and to tide over the capacity constraints of regional maritime forces. However, the involvement of external powers has its concomitant adversities in terms of 
regional security and stability. Such adversities may manifest in the following forms: -

Dominance- The preponderance of a single major power or a group of monolithic military allies is not desirable for the IndoPacific region. An example is the establishment of the British military base in Bahrain, which was undeniably planned in consort with the US, whether the stated purpose was anti-piracy, anti-ISIS, or anti-China.

Rivalry- The geopolitical rivalry among major powers, even if an adequate balance of power is achieved and maintained.

\section{Possible Adverse Scenarios}

- Politico-military interventions in response to political or socioeconomic instability in a regional country. It would be a race for being the first to intervene.

- Intervention in other forms using a natural disaster or manmade accident as an excuse. In 2008, during Cyclone Nargis, some Western countries invoked R2P in Myanmar. The intent may have been benign, but such actions clearly violate state sovereignty, which did not go down well with the smaller countries of the region. It is based on such risks that many regional countries have not acceded to the Search and Rescue (SAR) Convention, 1979.

- Rival powers may assist smaller regional countries, such as in capacity-building, but such assistance is often accompanied with further conditions, and at times, create military imbalances in a particular sub-region or region. The Chinese arms sales to the littoral countries of the IOR is case in point.

- Capacity building by major powers through the sale of defense hardware leads to regional polarisation. An unbridled and 'unqualified' capacity-building could lead to local instability or even the activation of maritime disputes.

- The preventive measures by some countries affected by sealevel rise may lead to a variety of unforeseen consequences, 
possibly with grave geopolitical and strategic ramifications for the stakeholders in the area. A case in point is the Maldives, whose government passed national legislation in July 2015 amending the national Constitution, which permits land reclamation by foreigners including China. Prior to the amendment, Article 251 of the Constitution prohibited foreign ownership of land. The amendment, however, permits land ownership by a foreign entity that invests more than the US \$ 1 billion in a project provided "at least 70 percent of the land must have been reclaimed from the ocean and visible at medium tide" (Maldives Amends Constitution to Allow Sale of Islands to Foreign Nationals, 2015).

\section{Conclusion}

A few facts distinguishing the 'sea' from the 'land' need to be noted by national policy-makers and analysts to understand the regional maritime security dynamics and tailor appropriate responses for ensuring the nation's maritime security. Unlike the affairs on land, in the maritime realm, national security interests and objectives reach far beyond the nation's frontiers and its littoral, into areas of maritime interest. India's primary and secondary areas of maritime interest - as articulated in India's Maritime Security Strategy (Ministry of Defence (Navy), 2015) - span the entire Indo-Pacific region. Also, unlike in the terrestrial domain, the non-traditional security threats to a nation's littoral and maritime interests often overlap with traditional military insecurities. Furthermore, unlike the non-traditional security issues within the land borders of countries, in the international medium of the seas, these security issues and the responses to them would invariably be accompanied by regional geopolitics. This could be in the form of regional countries and extra-regional stakeholders fulfilling their international commitments, or their actions driven by their own strategic interests and imperatives.

The aforesaid indicates that the insecurities emanating in and from the maritime realm are indeed more complex than land-based internal security challenges. This reinforces the imperative for 
synergy among the various national agencies and even commercial/private enterprises for effective national security response. This is particularly relevant for India, which needs to cover much ground in this regard.

\section{References}

BBC News. (2015, July). Egypt navy ship hit by Sinai militants missile. BBC News. Retrieved fromhttp://www.bbc.com/news/worldmiddle-east-33557180

Chatterjee, A. (2014). Private security companies at sea: solution or threat? NMF website. Retrieved from http:// www.maritimeindia.org/ Archives/PRIVATE-SECURITY-COMPANIES.html

Greenberg, M. D.,\& Chalk, P. Willis, H.V., Khilko, I. \& Ortiz, D.D. (2006). Maritime terrorism: risk and liability. RAND Corporation. Retrieved from

http:/ / www.rand.org/content/dam/rand/pubs/monographs/2006 /RAND_MG520.pdf

Hamid, I. H. (2015, May). Islam text books in Maldives breed hatred and fundamentalism, says NGO. Minivan News (Maldives). Retrieved fromhttp:/ / minivannewsarchive.com/politics/islam-text-books-inmaldives-breed-hatred-and-fundamentalism-says-ngo-98302\#sthash. oy S0GpsP.dpbs

Saunders, S. R. N. (Ed.). (2010). Janes fighting ships, 2010-11. Janes Information Group.

Khurana, G. S. (2007). Security of sea lines: prospects for India-Japan cooperation. Strategic Analysis, 31(1), 139 - 153.

Khurana, G. S. (2019). What is the Indo-Pacific? The new geopolitics of the Asia-Centred rim land. In A. Berkofski \& S. Miracola (Eds.) Geopolitics by other means. The Indo-Pacific reality, pp. 13-32. ISPI, LedizioniLedi Publishing: Milan, Italy. Retrieved from https://www.ispionline.it/sites/default/files/pubblicazioni/indopacific_web.def_.pdf\#page $=13$

Ministry of Defence (Navy). (2015). Ensuring secure seas: India's maritime security strategy. Integrated Headquarters.

Pianin E. (2014, October). ISIS delivers shock and awe with arms from U.S.., China and Russia. The Fiscal Times.Retrieved from http:/ / www.thefiscaltimes.com/2014/10/16/ISIS-Delivers-Shockand-Awe-Arms-US-China-and-Russia

The Statesman. (2015, September). Militia to mint coins, start its own economy. The Statesman (New Delhi), 12. 
The Washington Times. (2014, February). Al-Qaeda disavows any ties with radical Islamist ISIS group in Syria, Iraq. The Washington Times.Retrieved from https://www.washingtonpost.com/ world/ middle_east/al-qaeda-disavows-any-ties-with-radical-islamist-isisgroup-in-syria-iraq/2014/02/03/2c9afc3a-8cef-11e3-98abfe5228217bd1_story.html

The Wire. (2015, July). Maldives amends constitution to allow sale of islands to foreign nationals. The Wire. Retrieved from http:// the wire. in/2015/07/23/maldives-amends-constitution-to-allow-sale-ofislands -to-foreign-nationals-7035/

Times of India. (2015, September). Islamists plotted strike on Bangladesh navy bases. Times of India (New Delhi), p.14.

UN High Commissioner for Refugees (UNHCR).(2010). Convention and protocol relating to the status of refugees. Geneva.Retrieved from http://www.unhcr.org/3b66c2aa10.pdf 